How to cite this article:

Idris, A. A.., Bala, H., \& Ekumdayo O. (2020). Does size of the firm matter in the relationship between foreign ownership and dividend policy? Malaysian Management Journal, 24(July), 1-18. https://doi.org/10.32890/mmj.24.2020.9681

\title{
DOES SIZE OF THE FIRM MATTER IN THE RELATIONSHIP BETWEEN FOREIGN OWNERSHIP AND DIVIDEND POLICY?
}

\author{
*ADAMU IDRIS ADAMU \\ OYINDAMOLA EKUNDAYO \\ Department of Accounting, Faculty of Management Sciences \\ Federal University Dutsin-Ma, Nigeria \\ HUSSAINI BALA \\ Department of Accounting, Faculty of Management Sciences \\ Kaduna State University, Nigeria \\ *Corresponding author:adamuidris48@gmail.com
}

\begin{abstract}
Prior studies have revealed that foreign shareholders have a greater influence on dividend policy. However, it is unclear how foreign owners in large firms affect the propensity to pay dividends. This paper is aimed at exploring the relationship between the propensity to pay dividends and foreign ownership. It also examined the moderating role of firm size on the relationship between the decision to pay cash dividend and foreign ownership. The study uses pooled logistic regression on a data set of non-financial listed firms on the Nigerian Stock Market from 2011 to 2015. The results showed that foreign ownership has a great tendency to influence the propensity of a firm to pay a cash dividend. The effect is more pronounced in larger firms, thus, indicating that in larger firms, foreign owners mitigate agency problems using dividends. Based on the findings, firms should be encouraged to pay a dividend to attract foreign investors and in return will help the firms to acquire the expertise of foreign owners.
\end{abstract}


Keywords: Propensity to pay dividends, foreign ownership, firm size, Nigeria.

Received:1/5/2020 Revised: 2/6/2020 Accepted: 3/6/2020 Published: 30/8/2020

\section{Introduction}

Dividend policy is one of the most debated topics in the field of finance. This is because of its sensitivity to several factors, like firm and marketspecific characteristics. According to Baker and Weigand (2015), solving the dividend puzzle has now become an even more challenging phenomenon because every firm and market have peculiar characteristics and various possible forms of dividends substitutes. More recently, Tanveer and Jamil (2019) also stated that a dividend is very vital as firms continue to make its payments despite the difficulties faced by financial economists in their analyses. In addition to the size and form of dividends that a firm is expected to pay, managers first need to consider the likely factors that will necessitate its payment. Such factors may include ownership structure prevailing in the firm, its size, indebtedness, and maturity, among others.

The monitoring activities of foreign investors may be higher than those of domestic investors. Also, foreign investors may be less inclined to a dividend and are usually institutional investors from developed markets. Based on this assertion, Jeon and Ryoo (2013) argued that foreign owners are expected to maintain worldwide standards and best corporate governance practices. Furthermore, the foreign owners have stronger monitoring incentives and provide a greater control mechanism given the nature of their investments (large stakes and long-term investment style). In this regard, this current paper argues that foreign ownership, which is one form of ownership structure, could be a significant contributor to the financial policies of a firm. One of these policies is a firm's dividend payout. Foreign owners may use a dividend as a tool for controlling agency-related problems.

Before foreign owners invest their resources in any firm traded in an exchange market or otherwise, they must first carry out an analysis of such firm that include its size, corporate governance practices, financial performance and payout policies to mention but few. Prior works have indicated the significant effect of foreign owners on cash dividend. They include Nigeria (Abdulkadir, Abdullah \& Wong, 2016), Australia (Henry, 2011), Spain (Pucheta-Martínez \& López-Zamora, 2017), Korea (Jeon, Lee \& Moffett, 2011), China (Lam, Sami \& Zhou, 2012) and Jordan (Obaidat, 2018).

This paper uses a data sample of public listed non-financial firms in Nigeria from 2011-2015. The study chose the Nigerian market because of the distinct 
features that prevail in the market. First, there has been a decline in dividend payments in Nigeria. Only 124 of the 212 listed firms (58\%) paid dividends from 2011 to 2016, and only 33 percent of the payers were large capitalised firms (Awoyemi \& Bagga, 2016; NSE, 2016). Hence, this may lead to greater agency problems.

Nonetheless, this situation may provide a good avenue to examine the effect of firm size on the relationship between foreign ownership and the propensity to pay a dividend. First, the size of a firm is an important feature of a firm that may determine whether to pay a dividend in Nigeria (Abdulkadir, Abdullah $\&$ Woei-Chyuan, 2015). Second, the Nigerian market is viewed as a foreigninvestor driven market. According to Abdulkadir et al. (2015), foreign investors have dominated, as they account for 61.4 percent ownership across firms. The dominance is the result of the existing Nigerian corporate law that warrants foreign owners to hold up to 100 percent stake in any sector of the economy except for the oil and gas sector. Moreover, foreign participation in the NSE has continued to increase. For instance, 808 Billion Naira in 2012, 1,042 Billion Naira in 2013 and 1,539 Billion Naira in 2014 as compared to 509; 1,009; 1,137 Billion Naira for domestic participation in 2012, 2013 and 2014 respectively (NSE, 2015). Therefore, this may have a considerable effect on the dividend policy of the affected companies. Third, Nigerian company laws emanate from English law and as such are expected to be stronger in terms of shareholders protection (La Porta, Lopez-de-Silanes, Shleifer \& Vishny, 2000). However, this remains an illusion because the enforcement of the existing laws, regulations and implementation of corporate governance constitutes a major challenge (Okpara, 2011).

However, evidence on how foreign ownership impacts on cash dividends in larger firms remains scanty and unclear. This paper addressed this gap by examining the influential role of foreign ownership on the propensity to pay dividends in larger firms. This paper used a data sample of public listed nonfinancial firms in Nigeria from 2011-2015 with a final sample of 431 firm-year observations. The findings from the current study show that the association between foreign ownership and the propensity to pay dividends in large firms is positive and statistically Furthermore, with the introduction of firm size as a moderating variable, the result persists and becomes more positive, thus, suggesting that in larger firms, foreign investors are likely to use dividends to mitigate agency problem. The results findings contradicted the finding of (Abdulkadir et al., 2016) that documented a negative relationship between foreign ownership and (Lam et al., 2012).

This paper contributes to the dividend policy literature in the following ways. First, the paper examines how foreign ownership affects the propensity 
to pay dividends from one of the largest economies in the West African market. Second, the study adds to the literature by testing the moderating effect of size of the firm on the relationship between foreign ownership and the propensity to pay dividends thus suggesting that in larger firms where agency problems prevail, foreign investors may use dividend as a tool for controlling of managers' perquisite consumption. The rest of the paper is organised as follows: Section two discusses relevant literature and hypothesis development. The methodology is discussed in section three, while section four discusses the findings and the last section concludes the study.

\section{Literature Review and Hypothesis Development}

Prior studies have attempted to link the dividend policy puzzle to various theories. One of them is agency theory. This theory posits that a conflict of interest exists between managers and shareholders (Jensen \& Meckling, 1976). Shareholders who happen to be outside investors tend to benefit less from the capital they have invested in the firm because the managers prefer to maintain the cash or use it for perquisite consumption (Cao, Du \& Ørding, 2017). A dividend payment remedies the agency conflict associated with squandering of the available free cash flow in the firms (Easterbrook, 1984; Jensen, 1986).

Because managers prefer to maintain the cash in the firm, a need exists to have someone more powerful than the managers who will ensure that the cash is returned to the shareholders in the form of a dividend. To actualise this goal, well-informed investors are required who can induce the managers to pay dividends. Amongst these investors are foreign owners. Jeon and Ryoo (2013) posited that foreign owners are usually sophisticated investors and maintain worldwide standards and best corporate governance practices. This type of investor typically has considerable shareholdings and the requisite knowledge and ability to carefully monitor the managers (Cao et al., 2017). Based on these facts, the expectation is that their incentive to monitor managers could be higher compare to other investors with a more limited shareholding. In this regard, the foreign owners may have all channels of communication to the managers being opened to them and, therefore, encourage the managers to disburse free cash flow as a dividend. Sometimes, foreign owners may use multiple "carrot and stick" approaches or strategy to pressure powerful managers who have higher tendencies to exacerbate agency problems. As a result of such pressure by the foreign owners, these managers might reconsider their cash retention strategy force to disgorge a cash dividend to the shareholders. Florackis (2008) opined that financial carrots are a motivating factor that aligns the interests of the managers with those of the shareholders and, hence, mitigates the agency problems. 


\section{Foreign Ownership and Propensity to pay Dividends}

Conflicting results have been reported on the relationship between foreign ownership and dividend policy. According to Abdulkadir et al. (2016), a negative and statistically significant relationship existed between foreign ownership and the dividend payout decisions of the listed Nigerian firms during the period 2003-2012. Their finding suggests that firms are less likely to pay cash dividend as foreign shareholding is high. The result may be attributed to the tax imposed on dividend income. The country charges a withholding tax of $10 \%$ on dividend income whether the investor is foreign or domestic. Nevertheless, Jeon et al. (2011) found support for the preferences for dividends by foreign investors. Their study documented a positive and significant correlation between foreign ownership and the propensity to pay dividends in Korean markets. The study suggested that foreign shareholders have a strong incentive to monitor management in firms given their large holdings and investment styles. This finding also aligns with Cao et al. (2017), Hwang, Kim, Park and Park (2013), Obaidat (2018), and PuchetaMartínez and López-Zamora (2017) that the dividend paid becomes higher as the holdings of foreign investors increase. More recently, Bista, Bartaula, Shrestha, Gnawali, Lamichhane and Parajuli (2019) and Christopher and Chalid (2019) documented that foreign owners have positive effect on dividend policy in Nepalese and Indonesian firms respectively. These results supported the agency theory view of dividends. Consistent with these results and in support of the agency theory, the following hypothesis is posited.

$\mathrm{H}_{1}$ : There is a positive association between foreign ownership and the propensity to pay dividends.

Prior literature suggested the importance of firm size. Farinha (2003) argued that the size of the firm could be used as a proxy for agency costs. Larger firms are expected to have higher agency costs than smaller ones (Christopher \& Chalid, 2019). Moreover, Jensen and Meckling (1976) posited that managers have greater control in larger firms and in which ownership is dispersed such that shareholders have less incentive and ability to assume the monitoring activities. Thus, the level of agency problems and information asymmetry deepens. Also, evidence indicated that firm size is positively related to the propensity to pay a dividend (Abdulkadir et al., 2016; Fama \& French, 2001). Thus, including firm size as a moderating variable may provide an insight as to how foreign owners influence the propensity to pay dividends in larger firms. Thus, the following hypothesis is posited.

$\mathrm{H}_{2}$ : Firm size positively moderates the association between foreign ownership and propensity to pay dividends. 


\section{Methodology}

This study uses secondary sources of data and pooled logistic regression to test the predictions. Consistent with the literature (Baker, Dutta \& Saadi, 2008; Saeed \& Sameer, 2017), the study utilised non-financial listed firms from the Nigerian Stock Exchange (NSE). The sampling period is five years that covers a period between 2011 and 2015, with a total of 445 firm-year observations. Fourteen observations were dropped to minimise the effect of outliers in the sample. The final sample of the study was 431 firm-year observation. The selection of the period was related to the decline in the dividend payments in the exchange (Abdulkadir et al., 2016). Besides, there was a surge in the foreign portfolio during the period of study (NSE, 2015). The data were extracted from the annual reports of the listed firms.

\section{Variable Measurement}

\section{Dependent variable}

This study followed prior studies on the propensity to pay dividends (AlNajjar \& Kilincarslan, 2016; Arko, Abor, Adjasi \& Amidu, 2014; Idris, Ishak $\&$ Hassan, 2019) to model the dependent variable. The dependent variable was a binary variable, which was coded as 1 if a company paid a dividend and 0 if otherwise during the period of study.

\section{Independent variables}

The independent variable of this study was foreign ownership. Foreign ownership is measured as the proportion of shares held by foreign investors to the total number of shares in issue and is in line with Jeon et al. (2011) and Min and Bowman (2015). Firm size is FZE used as a moderating variable and represents the total assets of the firm (Farooq \& Ahmed, 2019). The dummy variable equalled 1 if the total assets were above the median value and 0 if otherwise. Prior evidence has shown that size of the firm is an important determinant of dividend policy decision. For instance, Fama and French (2001), Fatemi and Bildik (2012), and Hu and Kumar (2004) have affirmed that the likelihood of dividend payout depends on the size of the firm.

\section{Control variables}

Consistent with the literature on the propensity to pay dividends, this study uses four control variables that include firm leverage (LEV), sales growth (SGW) and retained profits (RET). FAGE is the number of years the firm 
has been listed on the stock exchange (Hu \& Kumar, 2004). LEV represents the total debt divided by total assets (Francis, Hasan, John \& Song, 2011). SGW is measured by current sales less previous sales divided by previous sales (Ferris, Jayaraman \& Sabherwal, 2009) RET is retained earnings scaled by total capital (Francis et al., 2011). BCM is board composition and is the proportion of outside directors on board and BSZ is board size and is the total number of executive and non-executive directors on board (Idris, Ishak $\&$ Hassan, 2017). Below are the two models used for the study. Model (1) is the direct model while model (2) is the interaction model:

$$
\begin{aligned}
\mathrm{PRD}_{i}= & \beta_{0}+\beta_{1} \mathrm{FOS}_{i}+\beta_{2} \mathrm{LEV}_{i}+\beta_{3} \mathrm{SGW}_{i}+\beta_{4} \mathrm{RET}_{i}+\beta_{5} \mathrm{BCM}_{i}+\beta_{6} \mathrm{BSZ}_{i}+\mathrm{e}_{i} \\
\mathrm{PRD}_{i}= & \beta_{7}+\beta_{8} \mathrm{FOS}_{i}+\beta_{9} \mathrm{FSZ}_{i}+\beta_{10} \mathrm{FOR}^{2} \mathrm{FSZ}_{i}+\beta_{11} \mathrm{LEV}_{i}+\beta_{12} \mathrm{SGW}_{i}+ \\
& \beta_{13} \mathrm{RET}_{i}+\beta_{14} \mathrm{BCM}_{i}+\beta_{15} \mathrm{BSZ}_{i}+\mathrm{e}_{i}
\end{aligned}
$$

where:

PRD = Propensity to pay dividends

$\mathrm{FOS}=$ foreign ownership

LEV $=$ Firm leverage

FSZ $=$ Firm size

$\mathrm{SGW}=$ Sales growth

RET $=$ Retained earnings

$\mathrm{BCM}=$ Board composition

$\mathrm{BSZ}=$ Board size

$\beta_{\mathrm{i}} \quad=$ Coefficients; $i=0,1, \ldots, 15$

$\mathrm{e}_{i} \quad=$ Error terms

\section{Descriptive Statistics}

\section{Results}

Table 1 reports the descriptive statistics of the variables used in the study. On the average, 50.6 percent of the sample firms paid cash dividends to their shareholders. The mean value of the dividend payers was lower when compared with what other markets have reported. For example, Francis et al. (2011) reported 52.4 percent for US market and Pucheta-Martínez and López-Zamora (2017) reported 55.76 percent for the Spanish market and higher than those that Saeed and Sameer (2017) reported for emerging markets (25.2\%) and Al-Najjar and Kilincarslan (2016) reported for Turkish market (33.9\%). The mean value of foreign ownership (FOS) was 56.4 percent. The mean was higher compared to prior studies like Abdulkadir et al. (2016) who reported 52.4 percent for the Nigerian market, and Cao et al., (2017) who reported 16.7 percent for the Chinese market. 
Malaysian Management Journal Vol. 24, July 2020 1-18

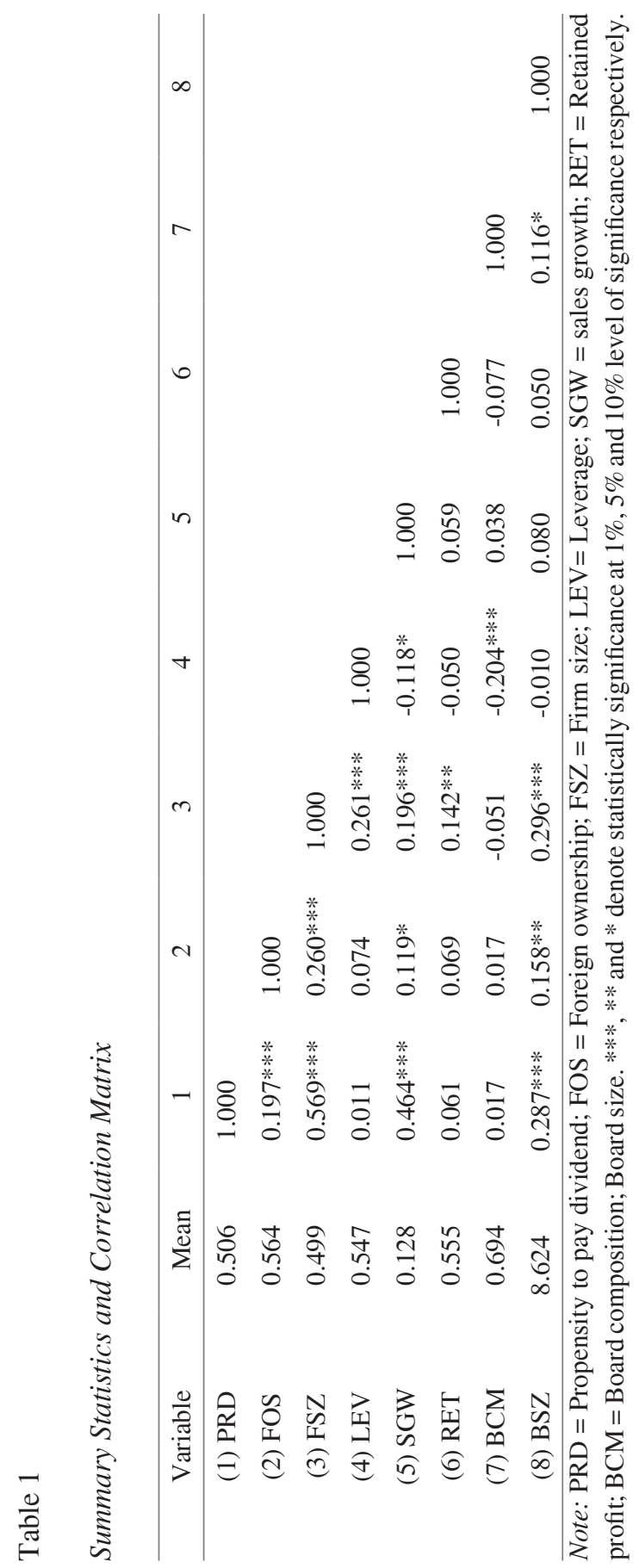


Table 1 provides the result of the correlation matrix to test for multicollinearity. The correlation matrix between the pairs was relatively low and was below 0.4 . None of the correlation coefficients was greater than 0.6, which may indicate multicollinearity concerns. Therefore, the models may not suffer from multicollinearity issues. The variables of interest in this correlation matrix were foreign ownership (FOS) and firm size (FSZ). As can be seen, PRD was positively related to FOS ( $\mathrm{r}=0.197)$ and FSZ (0.569). The sign of the correlation coefficient of the matrix may suggest the probable direction of the dependent and independent variable in the main regression equation.

Table 2 shows the summary statistics of dividend and non-dividend paying firms. As can be seen from the table, dividends paying firms have a higher percentage of foreign owners and are larger firms compared with nondividend paying firms. The data reveal a statistically significant difference between dividend and non-dividend paying firm at 1 percent. The result may yield as insight on presence as well as their effect on dividend-paying firms.

Table 2

Univariate Comparison of Dividend-Paying and Non-Dividend Paying Firms

\begin{tabular}{lccccc}
\hline \multicolumn{2}{l}{ Dividend-Paying firms. N=218 } & \multicolumn{3}{l}{ Non-Dividend Paying firms. N =213 } \\
\hline Variables & Mean & SD & Mean & SD & T-stat. \\
FOS & 0.661 & 0.475 & 0.465 & 0.500 & $-19.57 * * *$ \\
FSZ & 0.780 & 0.415 & 0.211 & 0.409 & $-56.85 * * *$ \\
LEV & 0.549 & 0.179 & 0.544 & 0.231 & -0.46 \\
SGW & 0.276 & 0.173 & -0.024 & 0.369 & $-29.97 * * *$ \\
RET & 0.567 & 0.176 & 0.543 & 0.211 & -2.38 \\
BCM & 0.696 & 0.121 & 0.691 & 0.126 & -0.42 \\
BSZ & 9.234 & 2.091 & 8.000 & 2.030 & $-123.39 * * *$ \\
\hline$N o t e:$ PRD $=$ Prop
\end{tabular}

Note: PRD = Propensity to pay dividend; FOS $=$ Foreign ownership; FSZ $=$ Firm size; $\mathrm{LEV}=$ Leverage; $\mathrm{SGW}=$ sales growth RET $=$ Retained profit $\mathrm{BCM}=$ Board composition; $\mathrm{BSZ}=$ Board size. ${ }^{* * *}$ denotes statistically significance at $1 \%$ level of significance.

\section{Regression Analysis}

Table 3 shows the results of the pooled logit regression for the direct and interaction models. As presented, two models are built for the dependent variable PRD that takes the value of one or zero. Column 1 presents the result of the direct relationship between foreign ownership and propensity 
to pay dividends. Column 2 is the result of the average marginal effect of the direct model for every variable in our study. The effect of firm size on the relationship between propensity to pay a dividend and foreign ownership along with its marginal effect, are presented in columns 3 and 4, respectively.

Furthermore, the results of large and small firms in terms of their total assets are shown in columns 5 to 8 , along with their marginal effects. Marginal effect is used to provide further economic significance of the variables. This is because coefficients estimated in logit regression do not provide a direct economic interpretation of the explanatory variables (Manos, Murinde \& Green, 2012). Hence, this study adopted average marginal effects to interpret economic significance.

The variable of interest here is foreign ownership. The findings from model 1 in column 1 lend support to hypothesis 1 . The result of the association between foreign ownership and propensity to pay dividends was positive and statistically significant. The average marginal effects confirm this result. All things being equal and on the average, a one-unit increase in the holdings of foreign investors will lead to an increase of $21.1 \%$ in the propensity to pay dividends among the listed firms on the NSE. This result agrees with previous evidence (Bista et al., 2019; Cao et al., 2017; Christopher \& Chalid, 2019; Hwang et al., 2013).

The result reported in Table 3 columns 3 to 4 shows that firm size positively moderates the relationship between foreign ownership and propensity to pay dividends. The coefficient of the interaction term (FOR*FSZ) is positive and statistically significant. Moreover, the economic significance of this term suggests that on the average, in larger firms, the presence of foreign owners will approximately result in a $35.50 \%$ increase in the likelihood of dividends paid. This result is in line with the hypothesis and aligns with previous studies (Cao et al., 2017; Hwang et al., 2013; Obaidat, 2018; Pucheta-Martínez \& López-Zamora, 2017). This suggests that in larger firms, foreign owners may tend to push for cash dividend payment and, hence, be willing to alleviate the agency conflict using dividend at the expense of tax. In other words, foreign owners consider eradicating an agency conflict as a matter of preference rather than capital gain due to the tax effect. Previous evidence argued that the prevalence of agency conflict was more pronounced in larger firms than in small firms (Farinha, 2003). Furthermore, larger firms are more mature and tend to have easier access to the capital markets, which reduces their dependence on internally generated funding (Fama \& French, 2001; Fatemi \& Bildik, 2012; Ferris, Sen \& Yui, 2006). This allows them to pay more cash dividends. The intensity of agency conflict and information asymmetry becomes greater in large firms since shareholders have less incentive in monitoring the managers (Jensen \& Meckling, 1976). 
Malaysian Management Journal Vol. 24, July 2020 1-18

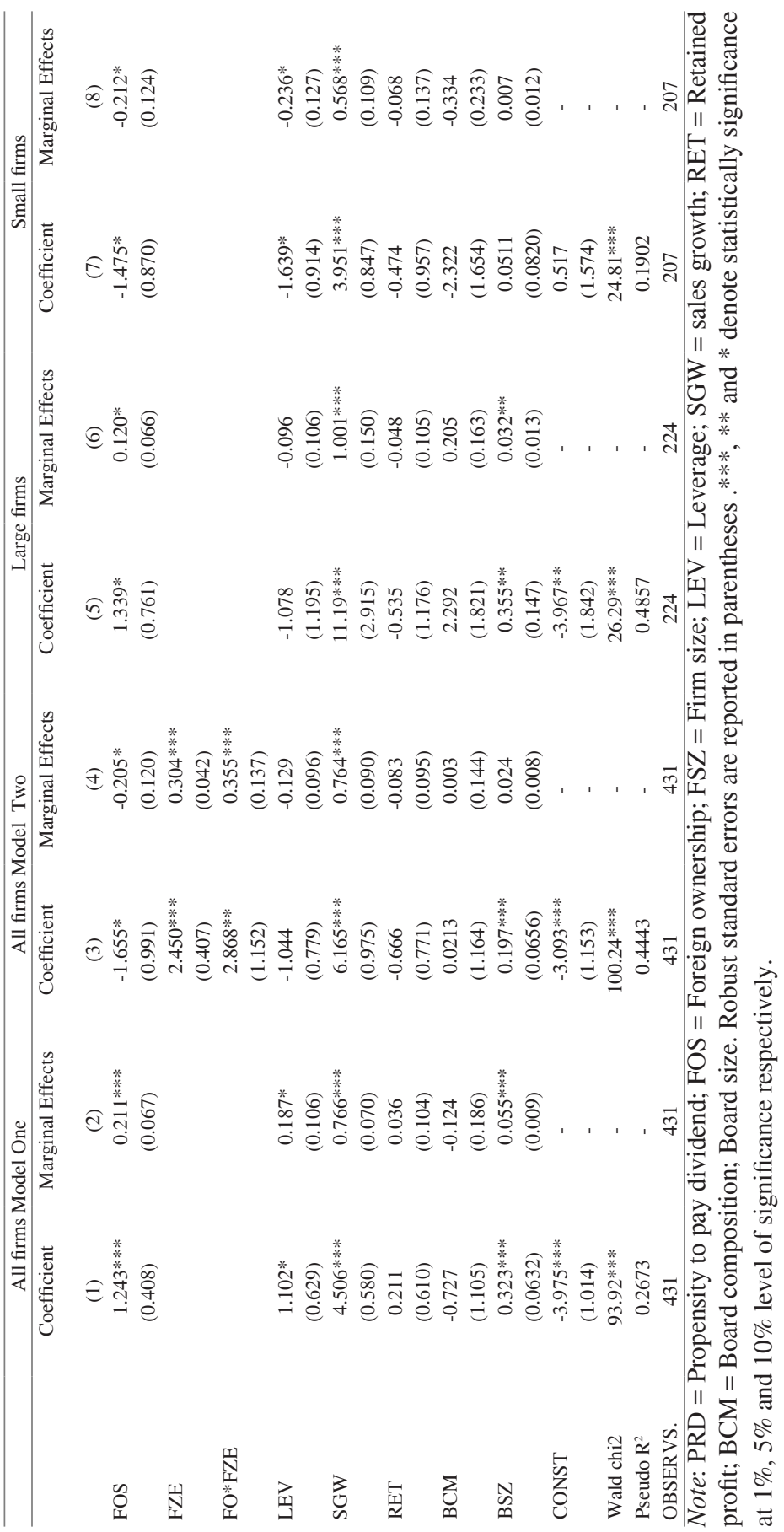


Furthermore, the result of the analysis in this study is revealing. In columns 5 to 8 , both the coefficient and marginal effect of foreign owners in larger firms were positive and statistically significant. This result conforms with the hypothesis that foreign investors in larger firms are more likely to influence the propensity to pay dividends and, hence, the findings are in conformity with agency theory.

Consequently, Table 3 shows the results of five control variables used in the study. Leverage, sales growth, and board size were positive and statistically significant. The result indicates that an indebted firm in the NSE has a higher likelihood of paying a cash dividend. The finding failed to agree with a prior expectation. With regards to sales growth, the result supports the prior evidence of Arko, Abor, Adjasi and Amidu (2014) that growth firms in Nigeria and South Africa found it necessary to pay dividends to make their shares in the capital market. The last control variable that was significant in this study was board size. The result reveals that a larger board was associated with a higher tendency to pay a cash dividend. This finding agrees with the agency theory and prior studies (Al-Najjar \& Kilincarslan, 2016; Idris et al., 2017).

\section{Robustness Tests}

This section provides robustness checks of the main findings of the study. First, the study checked for the sensitivity of the results shown in Tables 4 and 5. First, a dummy variable " 1 " was used if there were foreign owner in the firm in a year and " 0 " if otherwise. Then, the two models (direct and interaction model) were rerun. Table 4 presents the results (coefficient and marginal effects). The variable of interest in the two models in columns 1 and 3 remain positive and statistically significant. Thus, foreign owners influence the propensity to pay dividends.

Second, following Cao et al. (2017), foreign ownership was used as a dummy variable. High foreign was " 1 " if the percentage of foreign ownership holding was higher than the sample median and " 0 " if otherwise as an alternative measure of the independent variable. Second, a dummy variable of foreign ownership of " 1 " was used if a firm had foreign investors and " 0 " if otherwise. Table 5 presents the result. The results of these analyses remain intact, as previously reported in the main results. Thus, the findings are robust and are not sensitive to the change of the independent variable measurements. 
Table 4

Regression Results for High and Low Foreign Ownership

\begin{tabular}{|c|c|c|c|c|}
\hline & \multicolumn{2}{|c|}{ All firms Model One } & \multicolumn{2}{|c|}{ All firms Model Two } \\
\hline & $\begin{array}{l}\text { Coefficient } \\
\text { (1) }\end{array}$ & $\begin{array}{l}\text { Marginal } \\
\text { Effects } \\
(2)\end{array}$ & $\begin{array}{l}\text { Coefficient } \\
\text { (3) }\end{array}$ & $\begin{array}{l}\text { Marginal } \\
\text { Effects } \\
(4)\end{array}$ \\
\hline \multirow[t]{3}{*}{ FOS } & $0.821 * * *$ & $0.138 * * *$ & -0.190 & -0.023 \\
\hline & $(0.236)$ & $(0.038)$ & $(0.421)$ & $(0.052)$ \\
\hline & & & & (continued) \\
\hline \multirow[t]{2}{*}{ FZE } & & & $2.379 * * *$ & $0.291 * * *$ \\
\hline & & & $(0.418)$ & $(0.042)$ \\
\hline \multirow[t]{2}{*}{ FO*FZE } & & & $1.411 * * *$ & $0.173 * * *$ \\
\hline & & & $(0.531)$ & $(0.064)$ \\
\hline \multirow[t]{2}{*}{ LEV } & $1.173^{*}$ & $0.197 *$ & -1.266 & -0.155 \\
\hline & $(0.629)$ & $(0.105)$ & $(0.779)$ & $(0.094)$ \\
\hline \multirow[t]{2}{*}{ SGW } & $4.419 * * *$ & $0.744 * * *$ & $5.768 * * *$ & $0.706 * * *$ \\
\hline & $(0.571)$ & $(0.070)$ & $(0.865)$ & $(0.082)$ \\
\hline \multirow[t]{2}{*}{ RET } & 0.216 & 0.036 & -0.652 & -0.080 \\
\hline & $(0.618)$ & $(0.104)$ & $(0.768)$ & $(0.094)$ \\
\hline \multirow[t]{2}{*}{$\mathrm{BCM}$} & -0.748 & -0.126 & 0.269 & 0.033 \\
\hline & $(1.096)$ & $(0.183)$ & $(1.163)$ & $(0.142)$ \\
\hline \multirow[t]{2}{*}{ BSZ } & $0.310 * * *$ & $0.052 * * *$ & $0.190 * * *$ & $0.023 * * *$ \\
\hline & $(0.0635)$ & $(0.010)$ & $(0.0672)$ & $(0.008)$ \\
\hline \multirow[t]{2}{*}{ Constant } & $-3.967 * * *$ & - & $-3.200 * * *$ & - \\
\hline & $(1.011)$ & - & $(1.173)$ & - \\
\hline Wald chi2 & $101.92 * * *$ & - & $111.81 * * *$ & - \\
\hline Pseudo $\mathrm{R}^{2}$ & 0.2724 & - & 0.4491 & - \\
\hline Observations & 431 & 431 & 431 & 431 \\
\hline
\end{tabular}

Notes: $\mathrm{PRD}=$ Propensity to pay dividend; FOS = Foreign ownership; FSZ = Firm size; LEV = Leverage; $\mathrm{SGW}=$ sales growth RET = Retained profit BCM = Board composition; Board size. Robust standard errors are reported in parentheses. ***, $* *$ and $*$ denote statistically significance at $1 \%, 5 \%$ and $10 \%$ level of significance respectively. 
Malaysian Management Journal Vol. 24, July 2020 1-18






\section{Conclusions}

The paper examined the relationship between the propensity to pay dividends and foreign ownership. It also tested the effect of firm size as a moderating variable on the relationship between the propensity to pay dividends and foreign ownership in the context of agency theory. The empirical analysis revealed that foreign owners have a significant impact on influencing the payment of a cash dividend. Their effect is even more pronounced in larger firms. Therefore, the results support the claim of this study that the size of a firm moderates the relationship between foreign owners and the propensity to pay dividends. Overall, the findings indicated that foreign owners are important determiners of the likelihood of cash dividends. Hence, the study adds to the existing literature on agency theory.

The findings of this study have some policy implications. Firms should be encouraged to pay a dividend to attract foreign investors. This will, in turn, help the firms to acquire the expertise of foreign owners because they are more likely to possess critical knowledge that will enhance the performance of the firm. Moreover, the government should also reconsider its taxation policy on foreign owners by downward scaling of the rate. Thus, this will encourage the inflow of foreign investors in the NSE market and will allow the management to continue to pay dividends because paying them may be more beneficial to existing shareholders, particularly the foreign investors.

Based on the findings of this study, future study may consider the following, firstly to expanding the sample size and period to include more companies and years. Secondly, future studies may also consider analysing the identity of the foreign owners and the use of other agency theory related variables apart from the size of the firm as a moderator. Thirdly, examining some exchange markets in the sub-Saharan African and lastly, it would be interesting if financial firms were examined distinctively.

\section{Acknowledgement}

This research received no specific grant from any funding agency.

\section{References}

Abdulkadir, R. I., Abdullah, N. A. H., \& Woei-Chyuan, W. (2015). Dividend policy changes in the pre-, mid-, and post-financial crisis: Evidence 
from the Nigerian stock market. Asian Academy of Management Journal of Accounting and Finance, 11(2), 103-126.

Abdulkadir, R. I., Abdullah, N. A. H., \& Wong, W. C. (2016). Dividend payment behaviour and its determinants: The Nigerian evidence. African Development Review, 28(1), 53-63.

Al-Najjar, B., \& Kilincarslan, E. (2016). The effect of ownership structure on dividend policy: Evidence from Turkey. Corporate Governance: The International Journal of Business in Society, In Press. https://doi. org/10.1108/CG-09-2015-0129

Arko, A. C., Abor, J., Adjasi, C. K. D., \& Amidu, M. (2014). What influence dividend decisions of firms in Sub-Saharan African? Journal of Accounting in Emerging Economies, 4(1), 57-78.

Awoyemi, O., \& Bagga, R. (2016). Five years dividend payment review for NSE quoted companies. Retrieved from http://www.proshareng.com

Baker, H. K., Dutta, S., \& Saadi, S. (2008). Impact of financial and multinational operations on manager perceptions of dividends. Global Finance Journal, 19(2), 171-186.

Baker, H. K., \& Weigand, R. (2015). Corporate dividend policy revisited. Managerial Finance, 41(2), 126-144.

Bista, N. B., Bartaula, N. R., Shrestha, O., Gnawali, P., Lamichhane, P., \& Parajuli, P. (2019). Impact of corporate governance on dividend policy of Nepalese enterprises. In Business Governance and Society, Palgrave Macmillan, 377-397.

Cao, L., Du, Y., \& Ørding, J. (2017). Foreign institutional investors and dividend policy: Evidence from China. International Business Review, 26(5), 816-827.

Christopher, G., \& Chalid, D. A. (2019). Institutional investors and firms' cash dividend payments: Evidence from non-financial firms in Indonesia. Jurnal Pengurusan, 57.

Easterbrook, F. H. (1984). Two agency-cost explanations of dividends. American Economic Review, 74(4), 650-659.

Fama, E. F., \& French, K. R. (2001). Disappearing dividends: Changing firm characteristics or lower propensity to pay? Journal of Financial Economics, 60(1), 3-43.

Farinha, J. (2003). Dividend policy, corporate governance and the managerial entrenchment hypothesis: An empirical analysis. Journal of Business Finance and Accounting, 30(9-10), 1173-1209.

Farooq, O., \& Ahmed, N. (2019). Dividend policy and political uncertainty: Evidence from the US presidential elections. Research in International Business and Finance, In press. Retrieved from http://https://doi. org/10.1016/j.ribaf.2019.01.003

Fatemi, A., \& Bildik, R. (2012). Yes, dividends are disappearing: Worldwide evidence. Journal of Banking and Finance, 36(3), 662-677. 
Ferris, S. P., Jayaraman, N., \& Sabherwal, S. (2009). Catering effects in corporate dividend policy: The international evidence. Journal of Banking \& Finance, 33(9), 1730-1738.

Ferris, S. P., Sen, N., \& Yui, H. P. (2006). God save the queen and her dividends: Corporate payouts in the United Kingdom. The Journal of Business, 79(3), 1149-1173.

Florackis, C. (2008). Agency costs and corporate governance mechanisms: Evidence for UK firms. International Journal of Managerial Finance, 4(1), 37-59.

Francis, B. B., Hasan, I., John, K., \& Song, L. (2011). Corporate governance and dividend payout policy: A test using antitakeover legislation. Financial Management, 40(1), 83-112.

Henry, D. (2011). Ownership structure and tax-friendly dividends. Journal of Banking and Finance, 35(10), 2747-2760.

Hu, A., \& Kumar, P. (2004). Managerial entrenchment and payout policy. Journal of Financial and Quantitative Analysis, 39(04), 759.

Hwang, L. S., Kim, H., Park, K., \& Park, R. S. (2013). Corporate governance and payout policy: Evidence from Korean business groups. Pacific Basin Finance Journal, 24, 179-198.

Idris, A. A., Ishak, R., \& Hassan, N. (2019). Dividend payout among Nigerian firms : Do female directors matters? Jurnal Ekonomi Modernisasi, 15(1), 1-16.

Idris, A. A., Ishak, R., \& Hassan, N. L. (2017). Is there relationship between board structures and dividend policy: Evidence from Nigeria. Journal of Advanced Research in Business and Management Studies, 9(1), 1020.

Jensen, M. C. (1986). Agency costs of free cash flow, corporate finance, and takeovers. American Economic Review, 76(2), 323-329.

Jensen, M. C., \& Meckling, W. H. (1976). Theory of the firm : Managerial behavior, agency costs and ownership structure. Journal of Financial Economics, 3(4), 305-360.

Jeon, J. Q., Lee, C., \& Moffett, C. M. (2011). Effects of foreign ownership on payout policy: Evidence from the Korean market. Journal of Financial Markets, 14(2), 344-375.

Jeon, J. Q., \& Ryoo, J. (2013). How do foreign investors affect corporate policy? Evidence from Korea. International Review of Economics and Finance, 25(November 1997), 52-65.

La Porta, R., Lopez-de-Silanes, F., Shleifer, A., \& Vishny, R. (2000). Investor protection and corporate governance. Journal of Financial Economics, 58(1-2), 3-27.

Lam, K. C. K., Sami, H., \& Zhou, H. (2012). The role of cross-listing, foreign ownership and state ownership in dividend policy in an emerging market. China Journal of Accounting Research, 5(3), 199-216. 
Manos, R., Murinde, V., \& Green, C. J. (2012). Dividend policy and business groups: Evidence from Indian firms. International Review of Economics and Finance, 21(1), 42-56.

Min, B. S., \& Bowman, R. G. (2015). Corporate governance, regulation and foreign equity ownership: Lessons from Korea. Economic Modelling, $47,145-155$.

NSE. (2015). NSE domestic and foreign portfolio investment report. Retrieved from http://www.nse.com.ng/market_data-site/othermarket-information-site/FPI Report/Domestic and FPI Report December 2015.pdf

NSE. (2016). 2016, Closure of register - dividends and bonuses. Retrieved from https://www.nse.com.ng:8443/Issuers-section/corporate-disclosures/ corporate-actions/closure-of-register

Obaidat, A. N. (2018). Ownership structure and dividends policy : Emerging market evidence. International Business Research, 11(6), 65-72.

Okpara, J. O. (2011). Corporate governance in a developing economy: Barriers, issues, and implications for firms. Corporate Governance, 11(2), 184-199.

Pucheta-Martínez, M. C., \& López-Zamora, B. (2017). How foreign and institutional directorship affects corporate dividend policy. Investment Analysts Journal, 46(1), 44-60.

Saeed, A., \& Sameer, M. (2017). Impact of board gender diversity on dividend payments: Evidence from some emerging economies. International Business Review, 26(6), 1100-1113.

Tanveer, Z., \& Jamil, M. (2019). The impact of dividend announcement on stock returns among the ten top companies in Pakistan. Malaysian Management Journal, 23(December), 47-64. 